Jurnal Keperawatan Silampari

Volume 2, Nomor 1, Desember 2018

e-ISSN: 2581-1975

p-ISSN: 2597-7482

DOI: https://doi.org/10.31539/jks.v2i1.395

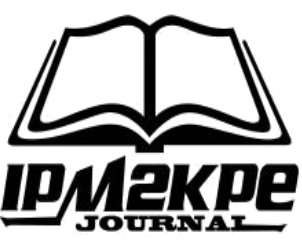

\title{
PENGARUH PSYCHOEDUCATIONAL PARENTING TERHADAP KECEMASAN ORANGTUA YANG MEMPUNYAI ANAK PENYANDANG THALASSEMIA MAYOR
}

\author{
Hera Hijriani \\ Program Studi Ilmu Keperawatan, STIKES YPIB Majalengka \\ herahafiz591@yahoo.com
}

\begin{abstract}
ABSTRAK
Penelitian ini bertujuan untuk mempelajari pengaruh psychoeducational parenting terhadap kecemasan orang tua yang mempunyai anak penyandang thalassemia mayor.Jenis penelitianini adalah penelitian quasi eksperiment menggunakan pendekatanpretest and posttest with control group design. Hasil penelitian menunjukkan bahwa terdapat pengaruh psychoeducational parenting terhadap kecemasan orang tua yang mempunyai anak penyandang thalassemia mayor ( $\mathrm{p}$ Value 0,006). Simpulan, terdapat pengaruh psychoeducational parenting terhadap kecemasan orang tua yang mempunyai anak penyandang thalassemia mayor. Tidak ada pengaruh faktor usia, pendidikan, pekerjaan, pendapatan keluarga, dan keberadaan anak penyandang thalassemia dalam keluarga terhadap kecemasan orang tua yang mempunyai anak penyandang thalassemia mayor.
\end{abstract}

Kata Kunci: Kecemasan, Psychoeducational Parenting, Thalassemia

\begin{abstract}
This study aims to study the effect of psychoeducational parenting on the anxiety of parents who have children with thalassemia major. This type of research is a quasiexperimental study using an interpretest and posttest with control group design approach. The results showed that there was an influence of psychoeducational parenting on the anxiety of parents who have children with thalassemia major ( $p$ value 0.006). Conclusion, there is the influence of psychoeducational parenting on the anxiety of parents who have children with thalassemia major. There is no influence of age, education, occupation, family income, and the presence of children with thalassemia in the family on the anxiety of parents who have children with thalassemia major.
\end{abstract}

Keywords: Anxiety, Psychoeducational Parenting, Thalassemia 


\section{PENDAHULUAN}

Menurut Kemenkes (2010) dalam Wahyu, H., Betrianita, B., Pramesti, M., \& Padila, P. (2018) menyatakan bahwa tumbuh kembang merupakan sebuah kesatuan yang mencerminkan perubahan - perubahan yang terjadi pada seseorang sepanjang fase kehidupannya. Proses Pertumbuhan dan perkembangan setiap anak tentu berbeda-beda dan memiliki kekhasan sendiri-sendiri. Permasalahan yang dihadapi juga tidak sama dari antara masing-masing anak.

Salah satunya indikator keberhasilan pembangunan dalam bidang kesehatan dapat dilihat dari tinggi rendahnya angka kematian ibu dan anak. Berdasarkan penelitian WHO diseluruh dunia terdapat kematian ibu sebesar 500.000 jiwa pertahun dan kematian bayi dan balita sebesar 10.000 jiwa per tahun. Kematian maternal dan balita tersebut terjadi terutama di negara berkembang sebesar $99 \%$. Kematian ibu di Indonesia masih berkisar 425/100.000 persalinan hidup. Sedangkan kematian bayi sekitar 56/10.000 persalinan hidup. Salah satu penyebab kematian pada ibu hamil adalah anemia dalam kehamilan (Manuaba, 2012) dalam Mariana, D., Wulandari, D., \& Padila, P. (2018).

Thalassemia merupakan masalah kesehatan utama, memberikan dampak emosional, psikologis dan ekonomi beragam pada jutaan orang di seluruh dunia (Old, Angastiniotis \& Petrou, 2013). Thalassemia termasuk penyakit autosomal resesif dari orang tua kepada anaknya yang disebabkan oleh defisiensi sintesis rantai polipeptida yang mempengaruhi sumsum tulang produksi hemoglobin dengan manifestasi klinis anemia berat (Potts, Mandleco, 2007). Thalassemia disebabkan oleh gen yang mempengaruhi bagaimana tubuh membuat hemoglobin, hilangnya protein dalam sel darah merah yang membawa oksigen. Anak-anak penyandang thalassemia memiliki sel darah merah yang beredar lebih sedikit dari biasanya dan membuat kurang hemoglobin, yang menghasilkan anemia mikrositik (Elsayed, 2015).

Anak yang di diagnosa thalassemia menunjukkan tanda dan gejala diantaranya gejala pusing, pucat, badan lemas, sukar tidur, tidak nafsu makan dan mudah infeksi. Anak penyandang thalassemia juga mengalami kelainan fisik seperti keterlambatan pertumbuhan, postur tubuh pendek, wajah spesifik thalassemia (facies colley) serta pembesaran hati dan limpa (spleenomegali) yang menyebabkan perutnya tampak menonjol. Komplikasi akibat hemosiderosis menyebabkan gangguan jantung, hati dan endokrin yang sering menyebabkan kematian (Hockenberry, Wilson, 2015). Perubahan dan kelemahan fisik tersebut berdampak secara psikososial pada anak thalassemia seperti rendah diri, malu dan tidak berdaya, anak bisa menarik diri dari lingkungan sosial (Jenerette, Valrie, 2010; Hockenberry, Wilson, 2015).

Data epidemiologi global thalassemia, melaporkan sekitar 68.000 anak-anak di dunia dilahirkan dengan berbagai sindrom thalassemia setiap tahunnya dan yang paling lazim adalah $\beta$-thalassemia (Taher, Vichinsky \& Musallam, 2013). Dari semua kelahiran thalassemia di dunia 95\% ditemukan di wilayah Mediterania, wilayah Asia, India, dan Timur Tengah. Di Mesir paling umum ditemukan $\beta$-Thalassemia $(85,1 \%)$, sebanyak 10.000 kasus thalassemia terdaftar dan lebih dari 20.000 kasus non-terdaftar (Elsayed, 2015). Di India, sekitar 32.000 kelahiran didapati anak lahir dengan thalassemia (Panja, 2012). Menurut Thallassemias International Federation (2011), Indonesia tergolongke dalam kelompok negara yang berisiko tinggi thalassemia, sedangkan menurut Kemenkes RI (2012) prevalensi carrier thalassemia di Indonesia sekitar 3-8\%. Jika persentase thalassemia mencapai 5\%, dengan angka kelahiran 23 per 
tahun dari 240 juta penduduk, maka diprediksi ada bayi penyandang thalassemia yang lahir setiap tahunnya.

Hasil riset Kesehatan Dasar (Riskesdas) (2013) menunjukkan bahwa prevalensi nasional thalassemia adalah $0,1 \%$. Beberapa dari 8 provinsi yang menunjukkan angka kejadian thalassemia lebih tinggi dari prevalensi nasional, yaitu Aceh 13,4\%, Jakarta $12,3 \%$, Sumatera Selatan 5,4\%, Gorontalo 3,1\%, dan Kepulauan Riau 3\%. Setiap tahun, 300 ribu anak dengan thalassemia akan dilahirkan dan sekitar 60-70 ribu diantaranya adalah jenis $\beta$-thalassemia mayor. Berdasarkan data yang diperoleh Yayasan Thalassemia Indonesia-Perhimpunan Orang tua Penderita Thalassemia (YTI-POPTI) Pusat, jumlah penduduk di Provinsi Jawa Barat \pm 43 juta jiwa, bila frekuensi pembawa sifat 5-10\% dan angka kelahiran 20\%, maka diperkirakan setiap tahunnyabayi thalassemia akan lahir sebanyak 500-600 orang (Wahyudi, 2011; http://web.rshs.or.id, 2017).

Anak penyandang thalassemia mayor memerlukan manajemen perawatan thalassemia yaitu transfusi darah seumur hidup secara teratur, hal ini berdampak psikososial bagi keluarganya terutama orang tuanya. Dampak psikososial pada orang tua dengan anak penyandang thalassemia adalah kecemasan (anxiety), tekanan emosional, ketakutan, perasaan bersalah, kesulitan menangani perasaan, bersikap over protectif, gangguan tidur, merasa tidak berharga (Jenerette, Valrie, 2010; Elsayed, 2015; Wong, 2009; Azizollah, tahmineh, \& Abdulghaffar, 2014). Hasil studi pada 150 orang tua, 95\% orang tua dari anak yang baru di diagnosa thalassemia mengungkapkan perasaan bingung dan shock, takut mati, putus asa, kecemasan pemisahan dan masalah dengan memori dan konsentrasi mereka (Khairkar, Malhotra \& Marwaha, 2010).

Kecemasan yang dirasakan orang tua pada anak dengan thalassemia disebabkan oleh ketidaktahuan keluarga tentang proses penyakit dan cara perawatannya dan rasa takut kehilangan anggota keluarga (Stuart, 2009). Kecemasan dapat dipengaruhi oleh dua faktor yaitu faktor internal yaitu usia, pengalaman, aset fisik dan faktor eksternalyaitu pengetahuan, pendidikan, pendapatan dan dukungan sosial (Zulfan, 2012). Sebagian besar orangtua dengan anak penyandang thalassemia menganggap kondisi anaknya merupakan suatu beban yang berat baik moral maupun material. Selain harus terus menerus memantau tumbuh kembang anak, orang tua membutuhkan biaya untuk transfusi darah yang tergolong sangat mahal. Selain itu, thalassemia merupakan penyakit yang diidap seumur hidup, artinya thalassemia merupakan penyakit yang tidak dapat sembuh. Tindakan medis hanya sebagai supportif dan bersifat sementara untuk mempertahankan hidup (Tamam, 2009).

Menurut hasil penelitian Astarani (2016) kecemasan orang tua yang mempunyai anak penyandang thalassemia menunjukkan kecemasan sedang. Hal ini disebabkanoleh jangka waktu mengasuh anak yang sudah cukup lama. Selain itu, usaha orangtua dalam mengobati dan menangani penyakit anak sudah sering sekali dilakukan sehingga pengalaman orangtua dalam menghadapi masalah yang terjadi pada anak sudah terbiasa. Namun, berbeda dengan mereka yang masih baru menyadari mengenai penyakit yang diderita oleh anaknya dapat menimbulkan kecemasan berat. Beberapa gejala kecemasan mereka diantaranya sering mengalami gangguan tidur, kelelahan, dan perubahan nafsu makan. Gejala emosional seperti perasaan bersalah dan marah menjadi gangguan psikologis orang tua.

Penyakit thalassemia merupakan salah satu penyakit kronis. Penyakit kronis bersifat permanen dan tidak pernah bisa disembuhkan secara tuntas, sehingga penyakit ini memerlukan keterlibatan secara penuh dari keluarga dalam memberikan 
perawatannya. Penyakit ini dapat mempengaruhi aspek baik penyandang thalassemia maupun keluarganya, misalnya gangguan fisik, psikologis, sosial, ekonomi dan spiritual. Keluarga yang anggotanya menyandang thalassemia, mempunyai resiko gangguan psikososial, dimana keluarga akan mengalami kecemasan dan berusaha menghadapi kecemasan tersebut dengan menggunakan koping yang efektif. Reaksi dan persepsi keluarga terhadap penyakit akan mempengaruhi semua aspek penyesuaian diri (Tamam, 2009).

Ada beberapa jenis intervensi yang dapat dilakukan untuk mengurangi dampak psikososial yang dialami oleh orang tua yang mempunyai anak penyandang thalassemia, salah satu intervensi yang dapat digunakan dalam berbagai kondisi dan dapat diberikan secara individual maupun kelompok adalah psychoe ducational parenting. Psychoe ducational adalah salah satu program perawatan kesehatan jiwa keluarga dengan cara pemberian informasi dan edukasi melalui komunikasi yang terapeutik. Program psychoeducational merupakan pendekatan yang bersifat edukasi dan pragmatic (Stuart, Laraia, 2009). Psikoedukasi adalah suatu upaya pendidikan kesehatan untuk mengatasi masalah psikososial bagi seseorang yang mengalami penyakit fisik maupun gangguan jiwa (Donker, Griffiths, Cuijpers \& Christensen, 2009).

Menurut Griffith (2006) dalam Zikrillah (2016) psikoedukasi termasuk salah satu intervensi keperawatan yang dapat dilakukan pada individu, keluarga dan kelompok dengan tujuan mendidik partisipannya mengenai tantangan signifikan dalam hidup, membantu partisipan mengembangkan sumber-sumber dukungan serta mengembangkan keterampilan koping untuk menghadapi tantangan tersebut. Psikoedukasi bukan merupakan suatu pengobatan, akan tetapi dirancang untuk menjadi bagian dari rencana perawatan secara keseluruhan (Supratiknya, 2011).

Studi yang dilakukan Cristensen (2011) pada 34 orang tua menunjukkan bahwa program psychoeducational untuk keluarga dapat mempengaruhi perubahan kecemasan keluarga dalam menghadapi anak dengan gangguan perilaku. Penelitian Widyaningrum (2015) rancangan penelitian yang digunakan dalam penelitiannya adalah eksperimen semu (quasy experiment) dengan non randomized control group pretest post test dengan jumlah sampel 28 responden (14 orang kelompok kontrol dan 14 orang kelompok eksperimen). Intervensi psikoedukasi dilakukan sebanyak 2 sesi, dan hasil menunjukkan bahwa terdapat perbedaan perubahan tingkat kecemasan keluarga dalam merawat penderita kanker serviks setelah dilakukan psikoedukasi. Selain itu, penelitian lain yang dilakukan oleh Duran (2016) pada 66 orang tua yang terdiri dari 33 orang kelompok eksperimen dan 33 orang kelompok kontrol, hasil penelitian menunjukkan bahwa psikoedukasi kepada orang tua efektif membantu meningkatkan kesejahteraan dan self compassion levels orang tua dari anak dengan kecacatan mental. Intervensi psikoedukasi yang diberikan dengan 8 sesi.

Penelitian ini mempunyai perbedaan dengan penelitian sebelumnya yaitu terletak pada subyek penelitian. Pada penelitian ini, yang akan menjadi subyek penelitiannya adalah orang tua dengan anak penyandang thalassemia mayor, sehingga implikasi dari penelitian ini yaitu psychoeducational parenting dapat menjadi salah satu alternatif prosedur intervensi keperawatan untuk mengatasi kecemasan orang tua yang mempunyai anakpenyandang thalassemia mayor di tempat penelitian. Selain itu, di RSUD Majalengka belum pernah dilakukan penelitian terkait psychoeducational parenting pada orang tua yang mempunyai anak penyandang thalassemia. 
Berdasarkan hasil wawancara dengan kepala bidang penelitian dan pengembangan (Litbang) serta penelaahan profil RSUD Majalengka, diperoleh jumlah penderita thalassemia sampai bulan Desember 2016 yang rutin berkunjung ke RSUD Majalengka mencapai 63orang. Perawatan anak thalassemia dilaksanakan di ruang perawatan anak dan jadwal transfusi/kontrol dilakukan 3 minggu sampai 1 bulan sekali. Hasil studi pendahuluan di RSUD Majalengka, dari hasil wawancara dengan lima orang tua dengan anak yang didiagnosa thalassemia mayor yaitu sebanyak tiga ibu mengalami kecemasan dengan gejala gangguan tidur, merasa kelelahan dan mengalami perubahan nafsu makan. Meskipun, Orang tua mengetahui penyakit anaknya, namun mereka belum memahami tentang proses penyakit, perawatan dan pengobatan thalassemia. Orang tua mengatakan bahwa ketika anaknya didiagnosa thalassemia mereka merasa marah, sedih dan mereka takut kehilangan anaknya.

Hasil wawancara dengan kepala ruang anak RSUD Majalengka kegiatan psychoeducational kepada keluarga belum pernah dilaksanakan, karena tenaga perawat yang mampu untuk melakukan terapi psikoedukasi pada keluarga masih tidak ada, selain itu waktu yang sangat terbatas untuk melakukan kegiatan tersebut karena perawatan untuk anak dengan thalassemia dilakukan di ruang perawatan anak dengan penyakit lain. Anak-anak tergantung pada orang tua mereka untuk membantu mengenali dan memenuhi kebutuhan mereka, sehingga pendidikan dan dukungan untuk anak dan orang tua tentang gangguan dan pengobatan sangat penting, dimana keluarga dan anak dengan thalassemia mayor beresiko mengalami peningkatan masalah psikososial. Penelitianini bertujuanuntuk mengidentifikasi pengaruh psychoeducational parenting terhadap kecemasan orang tua yang mempunyai anak penyandang thalassemia mayor.

\section{METODE PENELITIAN}

Jenis penelitian yang digunakan adalah penelitian kuantitatif dengan desain Quasi eksperiment. Penelitian Quasi eksperiment merupakan penelitian yang mengujicobakan suatu intervensi pada sekelompok subjek dengan atau tanpa kelompok pembanding, namun tidak dilakukan randomisasi untuk memasukan subjek ke dalam kelompok perlakuan atau kontrol. Desain penelitian yang digunakan adalah pretest and posttestwith controlgroup design, dengan intervensi psychoeducational parenting. Populasi pada penelitian ini adalah orang tua yang mempunyai anak penyandang thalassemia mayor di RSUD Majalengka yaitu sebanyak 63 orang. Sampel minimal yang dibutuhkan dalam penelitian ini adalah 19 responden. Untuk mengantisipasi kemungkinan responden terpilih yang drop out pada saat penelitian, dengan perkiraan sebesar 10\%. Dengan demikian besar sampel setelah dikoreksi menjadi 21 responden. Teknik pengambilan sampel dalam penelitian ini, menggunakan teknik consecutive sampling, yang merupakan jenis non-probability sampling yang paling baik, dan seringkali merupakan cara yang termudah (Sastroasmoro, Ismael, 2011).

Penelitian ini dilakukan di RSUD Majalengka Jawa Baratselama 5 bulan yang dimulai pada bulan Maret sampai dengan Juli 2017. Analisis datanya meliputi analisis univariat, bivariat dan multivariat. Analisis univariat pada penelitian ini menggunakan analisis proporsi untuk variabel berbentuk kategorik (pendidikan, pekerjaan, pendapatan dan jumlah anak yang menyandang thalassemia) dan dituangkan dalam tabel distribusi frekuensi. Variabel dengan data yang berbentuk numerik (usia dan kecemasan) menggunakan mean, median, modus dan standar deviasi. Uji statistik dengan uji-t dependent (paired sample $t$ test) untuk menguji perbedaan rata-rata mengenai kecemasan sebelum dan sesudah diberikan intervensi pada kelompok eksperimen 
(psychoeducational parenting) dan kelompok kontrol (pendidikan kesehatan biasa) dan uji-t independen untuk menguji signifikansi perbedaan skor rata-rata antar kelompok. Analisis multivariat dilakukan untuk melihat sejauh mana pengaruh variabel independen dan variabel lainnya yang diteliti yaitu usia, jumlah anak yang menderita thalassemia dalam keluarga, pendidikan, pekerjaan dan pendapatan dengan variabel dependen yaitu kecemasan menggunakan uji regresi logistik ganda.

\section{HASIL PENELITIAN}

Tabel. 1

Distribusi Responden Berdasarkan Usia, Pendidikan, Pekerjaan, Pendapatan, dan Keberadaan Anak Penyandang Thalassemia dalam Keluarga (n1=21; n2=21)

\begin{tabular}{|c|c|c|c|c|}
\hline \multirow{2}{*}{\multicolumn{2}{|c|}{ Variabel }} & \multicolumn{2}{|c|}{ Kelompok } & \multirow{2}{*}{$\mathrm{P}$} \\
\hline & & Eksperimen & Kontrol & \\
\hline \multirow[t]{5}{*}{ Usia } & Mean & 33,66 & 33.62 & $0,972^{\mathrm{a}}$ \\
\hline & Median & 33,00 & 32,00 & \\
\hline & $\mathrm{SD}$ & 4,68 & 4,17 & \\
\hline & Min & 26,00 & 27,00 & \\
\hline & Max & 42,00 & 44,00 & \\
\hline \multirow[t]{2}{*}{ Pendidikan } & Rendah & $66,7 \%$ & $61,9 \%$ & $1,000^{b}$ \\
\hline & Tinggi & $33,3 \%$ & $38,1 \%$ & \\
\hline \multirow[t]{2}{*}{ Pekerjaan } & Tidak Bekerja & $42,9 \%$ & $47,6 \%$ & $1,000^{\mathrm{b}}$ \\
\hline & Bekerja & $57,1 \%$ & $52,4 \%$ & \\
\hline \multirow[t]{2}{*}{ Pendapatan } & $<$ UMR & $38,1 \%$ & $23,8 \%$ & $0,504^{b}$ \\
\hline & $\geq \mathrm{UMR}$ & $61,9 \%$ & $76,2 \%$ & \\
\hline \multirow{2}{*}{$\begin{array}{l}\text { Keberadaan anak } \\
\text { thalassemia dalam } \\
\text { keluarga }\end{array}$} & $\geq 2$ orang & $9,5 \%$ & $14,3 \%$ & $1,000^{b}$ \\
\hline & 1 orang & $90,5 \%$ & $85,7 \%$ & \\
\hline
\end{tabular}

Sumber : Data Primer Kuesioner, 2017

Berdasarkan tabel di atas, terlihat pada variabel usia diperoleh hasil bahwa ratarata usia orang tua pada kelompok eksperimen adalah 33,66 tahun dengan deviasi sebesar 4,68. Sementara rata-rata usia orang tua pada kelompok kontrol adalah 33,62 tahun dengan standar deviasi 4,17. Uji Homogenitas pada dua kelompok dengan menggunakan uji T Independen memperlihatkan nilai p sebesar 0,972. Berdasarkan nilai p tersebut dapat disimpulkan bahwa tidak terdapat perbedaan rata-rata usia antara kelompok eksperimen dengan kelompok kontrol, hal ini berarti dilihat dari variabel usia antara kelompok eksperimen dengan kelompok kontrol ada pada keadaan homogen.

Variabel pendidikan memperlihatkan bahwa pendidikan orang tua pada kelompok eksperimen dan kelompok kontrol memiliki sebaran yang hampir merata yaitu pendidikan orang tua berada pada tingkat pendidikan rendah. Pengujian homogenitas antara kedua kelompok dengan menggunakan uji chi-square diperoleh nilai $\mathrm{p}$ sebesar 1,000 disimpulkan bahwa tidak terdapat perbedaan proporsi pendidikan antara kelompok eksperimen dan kelompok kontrol ada dalam keadaan homogen.

Hasil analisis untuk variabel pekerjaan didapatkansebagian besar orang tuabekerja yaitu pada kelompok eksperimen sebanyak 12 orang $(57,1 \%)$ dan pada kelompok kontrol sebanyak 11 orang $(52,4 \%)$. Uji homogenitas pada kedua kelompok dengan menggunakan uji chi-square memperlihatkan nilai $\mathrm{p}$ sebesar 1,000 sehingga 
disimpulkan bahwa tidak terdapat perbedaan proporsi pekerjaan antara kelompok eksperimen dan kelompok kontrol.

Variabel pendapatan didapatkan bahwa pada kelompok eksperimen dan kelompok kontrol didapatkan sebagian besar responden pendapatannya diatas UMR.Uji homogenitas pada kedua kelompok dengan menggunakan uji chi-square memperlihatkan nilai $\mathrm{p}$ sebesar 0,504 , sehingga disimpulkan bahwa tidak terdapat perbedaan proporsi pekerjaan antara kelompok eksperimen dan kelompok kontrol.

Variabel keberadaan anak penyandang thalassemia dalam keluarga pada kelompok eksperimen dan kelompok kontrol didapatkan bahwa sebagian besar responden mempunyai 1 anak penyandang thalassemia dalam keluarga. Pengujian homogenitas pada kedua kelompok dengan menggunakan uji chi-square diperoleh nilai $\mathrm{p}$ sebesar 1,000, disimpulkan tidak terdapat perbedaan proporsi keberadaan anak penyandang thalassemia dalam keluarga.

Tabel. 2

Perbedaan Skor Rata-Rata Kecemasan Sebelum dan Sesudah Intervensi pada Kelompok Eksperimen dan Kelompok Kontrol

\begin{tabular}{|c|c|c|c|c|c|c|}
\hline \multirow{3}{*}{\multicolumn{2}{|c|}{ Variabel }} & \multirow{3}{*}{$\begin{array}{c}\text { Skor } \\
\text { Kecemasan } \\
(\mathrm{N}=42)\end{array}$} & \multicolumn{4}{|c|}{ Kelompok } \\
\hline & & & \multicolumn{2}{|c|}{ Eksperimen } & \multicolumn{2}{|c|}{ Kontrol } \\
\hline & & & Pre & Post & Pre & Post \\
\hline \multirow[t]{5}{*}{ Kecemasan } & Mean & 58,95 & 59.04 & 50,28 & 58,85 & 52,90 \\
\hline & Median & 59,00 & 59,00 & 50,00 & 59,00 & 53,00 \\
\hline & SD & 1,26 & 1,16 & 2,64 & 1,38 & 3,19 \\
\hline & Min & 56,00 & 57,00 & 46,00 & 56,00 & 47,00 \\
\hline & Maks & 62,00 & 61,00 & 55,00 & 62,00 & 60,00 \\
\hline \multicolumn{3}{|c|}{$\begin{array}{l}\text { Selisih rata-rata skor kecemasan masing-masing } \\
\text { kelompok }(\Delta)\end{array}$} & \multicolumn{2}{|c|}{$-8,26$} & \multicolumn{2}{|c|}{$-5,95$} \\
\hline \multicolumn{3}{|c|}{$\begin{array}{l}\text { Signifikansi Perbedaan Skor Rata-rata pre dan post } \\
\text { pada masing-masing Kelompok (p Value) }\end{array}$} & \multicolumn{2}{|c|}{$0,000^{\mathrm{a}}$} & \multicolumn{2}{|c|}{$0,000^{\mathrm{a}}$} \\
\hline \multirow{2}{*}{\multicolumn{3}{|c|}{$\begin{array}{l}\text { Signifikansi Perbedaan Skor Rata-rata Antar } \\
\text { Kelompok }\end{array}$}} & \multirow{2}{*}{\multicolumn{2}{|c|}{ Pre }} & \multicolumn{2}{|c|}{$0,632^{\mathrm{b}}$} \\
\hline & & & & & \multicolumn{2}{|c|}{$0.006^{\mathrm{b}}$} \\
\hline
\end{tabular}

Sumber : Data Primer Kuesioner, 2017

Keterangan :

a : Signifikansi Uji t Dependen

b : Signifikansi Uji t Independen

Berdasarkan tabel di atas, diperoleh gambaran kecemasan sebelum intervensi (pretest) yaitu pada kelompok eksperimen skor rata-rata kecemasan 59,04 dengan standar deviasi 1,16, skor kecemasan terendah adalah 57,00 dan kecemasan tertinggi adalah 61,00. Sementara pada kelompok kontrol skor rata-rata kecemasan 58,85 dengan standar deviasi 1,38 dan skor kecemasan terendah adalah 56,00 sedangkan kecemasan tertinggi adalah 62,00. Gambaran kecemasan sesudah Intervensi (posttest) yaitu pada kelompok eksperimen skor rata-rata kecemasan sesudah perlakuan adalah 50,28 dengan standar deviasi 2,64 dan kecemasan terendah 46,00 sedangkan kecemasan tertinggi 55,00. Sementara pada kelompok kontrol skor rata-rata kecemasan yaitu 52,90 dengan standar deviasi 3,19 dan kecemasan terendah 47,00 sedangkan kecemasan tertinggi 60,00. Pengujian statistik pre intervensi (sebelum) diperoleh nilai p Value sebesar 0,632, ini menunjukan tidak terdapat perbedaan skor kecemasan pada kelompok eksperimen dan kelompok kontrol. Pengujian statistik pada post intervensi (sesudah) diperoleh nilai $\mathrm{p}$ value sebesar 0,006, dapat disimpulkan bahwa terdapat perbedaan skor kecemasan 
pada kelompok eksperimen dan kelompok kontrol, dimana skor rata-rata kecemasan padakelompok eksperimen lebih rendah $(50,28)$ dibanding kelompok kontrol $(52,90)$.

Berdasarkan tabel di atas, didapatkan hasil bahwa terdapat perbedaan skor kecemasan sebelum dan sesudah pemberian intervensi psychoeducational parenting pada kelompok eksperimen dengan rata-rata penurunan sebesar 8,26. Terdapat perbedaan skor kecemasan sebelum dan sesudah pemberian intervensi berupa pendidikan kesehatan pada kelompok kontrol dengan rata-rata penurunan sebesar 5,95.

Tabel. 3

Pemodelan Bertahap Regresi Logistik Kecemasan didasarkan Usia, Pendidikan, Pekerjaan, Pendapatan, Keberadaan Anak Penyandang Thalassemia dan Intervensi

\begin{tabular}{|c|c|c|c|c|c|c|c|}
\hline \multirow{2}{*}{ Tahap } & \multirow{2}{*}{ Variabel } & \multirow{2}{*}{ B } & \multirow{2}{*}{ Wald } & \multirow[b]{2}{*}{ Sig } & \multirow[b]{2}{*}{$\operatorname{Exp}(B)$} & \multicolumn{2}{|c|}{$95 \% \mathrm{CI}$} \\
\hline & & & & & & Lower & Upper \\
\hline \multirow[t]{7}{*}{1.} & Usia & 0,107 & 1,667 & 0,197 & 1,113 & 0,946 & 1,309 \\
\hline & Pendidikan & $-0,604$ & 0,652 & 0,419 & 0,547 & 0,126 & 2,367 \\
\hline & Pekerjaan & 0,049 & 0,004 & 0,947 & 1,050 & 0,248 & 4,438 \\
\hline & Pendapatan & 0,232 & 0,083 & 0,773 & 1,261 & 0,261 & 6,103 \\
\hline & Keberadaan anak thalasemia & $-0,460$ & 0,190 & 0,663 & 0,631 & 0,080 & 4,998 \\
\hline & Intervensi & $-1,500$ & 4,502 & 0,034 & 0,223 & 0,056 & 0,892 \\
\hline & Konstanta & 0,086 & 0,001 & 0,980 & 1,090 & & \\
\hline \multirow[t]{6}{*}{2.} & Usia & 0,107 & 1,673 & 0,196 & 1,113 & 0,946 & 1,309 \\
\hline & Pendidikan & $-0,600$ & 0,648 & 0,421 & 0,549 & 0,128 & 2,363 \\
\hline & Pendapatan & 0,250 & 0,109 & 0,741 & 1,284 & 0,291 & 5,661 \\
\hline & Keberadaan anak thalasemia & $-0,454$ & 0,187 & 0,666 & 0,635 & 0,081 & 4,970 \\
\hline & Intervensi & $-1,506$ & 4,594 & 0,032 & 0,222 & 0,056 & 0,879 \\
\hline & Konstanta & 0,117 & 0,001 & 0,973 & 1,124 & & \\
\hline \multirow[t]{5}{*}{3.} & Usia & 0,109 & 1,752 & 0,186 & 1,115 & 0,949 & 1,311 \\
\hline & Pendidikan & $-0,618$ & 0,697 & 0,404 & 0,539 & 0,127 & 2,298 \\
\hline & Keberadaan anak thalasemia & $-0,415$ & 0,161 & 0,689 & 0,660 & 0,087 & 5,034 \\
\hline & Intervensi & $-1,464$ & 4,536 & 0,033 & 0,231 & 0,060 & 0,890 \\
\hline & Konstanta & 0,362 & 0,012 & 0,914 & 1,436 & & \\
\hline \multirow[t]{4}{*}{4} & Usia & 0,107 & 1,707 & 0,191 & 1,113 & 0,948 & 1,308 \\
\hline & Pendidikan & $-0,653$ & 0,801 & 0,371 & 0,521 & 0,125 & 2,175 \\
\hline & Intervensi & $-1,439$ & 4,451 & 0,035 & 0,237 & 0,062 & 0,903 \\
\hline & Konstanta & $-0,348$ & 0,015 & 0,903 & 0,706 & & \\
\hline \multirow[t]{3}{*}{5} & Usia & 0,096 & 1,448 & 0,229 & 1,101 & 0,941 & 1,288 \\
\hline & Intervensi & $-1,454$ & 4,605 & 0,032 & 0,234 & 0,062 & 0,882 \\
\hline & Konstanta & $-0,831$ & 0,091 & 0,763 & 0,436 & & \\
\hline \multirow[t]{2}{*}{6} & Intervensi & $-1,402$ & 4,515 & 0,034 & 0,246 & 0,068 & 0,897 \\
\hline & Konstanta & 2,318 & 4,733 & 0,030 & 10,156 & & \\
\hline
\end{tabular}

Sumber : Data Primer Kuesioner, 2017

Berdasarkan model akhir dari analisis multivariat di atas, menunjukkan proses pengeliminasian variabel yang tidak memiliki pengaruh secara signifikan dalam membentuk model kecemasan didasarkan pada 6 variabel yang diteliti. Pengeliminasian dilakukan dengan mendasarkan pada $\mathrm{p}$ value masing-masing variabel dimana $\mathrm{p}$ value tertinggi dieliminir dari model. Hasil pada tahap pertama adalah dilakukannya pengeliminasian pada variabel pekerjaan ( $\mathrm{p}$ value 0,947 ). Tahap kedua pengeliminasian variabel pendapatan ( $\mathrm{p}$ value 0,741 ). Tahap ketiga pengeliminasian variabel keberadaan anak penyandang thalassemia dalam keluarga ( $\mathrm{p}$ value 0,689). Tahap keempat pengeliminasian variabel pendidikan ( $\mathrm{p}$ value 0,371 ). Tahap kelima pengeliminasian variabel usia ( $\mathrm{p}$ value 0,229 ). Pada akhir proses eliminasi variabel yang tidak signifikan 
mempengaruhi kecemasan, ditemukan model bahwa kecemasan dipengaruhi oleh variabel intervensi. Pada tabel diatas juga dapat menyimpulkan pemodelan ringkas yang dapat menjelaskan hubungan variabel intervensi dengan kecemasan, adalah sebagai berikut: 2,318 - 1,402 (intervensi)+E (faktor lain yang tidak diteliti). Dari persamaan tersebut dapat disimpulkan bahwa: Bila tidak dilakukan intervensi psychoeducational parenting akan meningkatkan kecemasan sebesar 2,318 dibanding faktor lain yang tidak diteliti.

\section{PEMBAHASAN}

Hasil penelitian menunjukkan bahwa rata-rata kecemasan pada kelompok eksperimen sebelum perlakuan sebesar 59,04 (cemas ringan) dan sesudah perlakuan sebesar 50,28 (cemas ringan), terdapat penurunan kecemasan sebesar 8,76. Hal ini sesuai dengan pendapat Stuart (2013) bahwa psikoedukasi keluarga merupakan salah satu cara yang dapat dilakukan oleh perawat dalam memberikan pelayanan yang efektif dan efisien untuk penyelesaian masalah psikologis yang berkaitan dengan masalah fisik keluarga.

Hasil analisis pada kelompok eksperimen menunjukkan bahwa ada penurunan secara statistik dengan nilai $\mathrm{p}$ value $=0.000$ ( $\mathrm{p}$ value $<0.05$ ). Hal ini membuktikan bahwa terdapat perbedaan yang signifikan kecemasan pada kelompok eksperimen sebelum dan sesudah pemberian psychoeducational parenting. Perbedaan rerata kecemasan pada kelompok eksperimen sesudah diberikan psychoeducational parenting membuktikan adanya pengaruh yang positif pemberian Psychoeducational parenting. Psychoeducational parenting mampu meningkatkan kemampuan keluarga dalam mengatasi kecemasan. Psychoeducational parenting ini sejalan dengan konsep dari keperawatan anak bahwa konsep perawatan berpusat pada keluarga (Family Centered Care). Filosofi FCC yaitu keluarga merupakan bagian yang tidak dapat dipisahkan dalam kehidupan anak. Anak adalah bagian dari keluarga, maka kehidupan anak dapat ditentukan oleh lingkungan keluarga, untuk itu keperawatan anak harus mengenal keluarga sebagai tempat tinggal atau sebagai konstanta tetap dalam kehidupan anak (Wong, 2009). Sistem pelayanan kesehatan dan seluruh tenaga kesehatan harus mendukung, menghargai, mendorong dan meningkatkan kekuatan dan kompetensi keluarga dengan mengembangkan kemitraan dengan keluarga (Wong, 2009).

Sesuai dengan konsep dalam family centered care yaitu enabling (memampukan) dan empowering (pemberdayaan),Psikoedukasi merupakan proses empowerment untuk mengembangkan dan menguatkan keterampilan yang sudah dimiliki oleh individu untuk menekan munculnya gangguan psikologis, selain itu dapat diterapkan sebagai bagian dari persiapan orang tua untuk menghadapi kenyataan tentang adanya anggota keluarga yang sedang sakit. Orang tua mempunyai hak untuk memutuskan apa yang penting untuk dirinya dan keluarganya (Wong, 2009).

Hasil penelitian yang menunjukkan bahwa psikoedukasi terdapat pengaruhnya pada kecemasan, sesuai dengan penelitian Widyaningrum (2015) menunjukkan bahwa psikoedukasi yang dilakukan sebanyak 2 sesi, menurunkan tingkat kecemasan keluarga. Juga penelitian Lestari (2011) tentang pengaruh psikoedukasi terhadap pengetahuan dan tingkat ansietas keluarga dalam merawat anggota keluarga yang mengalami TBC Paru, menunjukkan bahwa psikoedukasi lebih efektif dalam penatalaksanaan terhadap psikososial seseorang terutama yang mengalami kecemasan.

Hasil penelitian lain yang menunjukkan bahwa intervensi psychoeducational parenting efektif menurunkan kecemasan orang tua yaitu penelitian yang dilakukan oleh 
Cristensen (2011) bahwa program psychoeducational parenting mempengaruhi perubahan kecemasan keluarga dalam menghadapi anak dengan gangguan perilaku. Hasil penelitian lain yang dilakukan Rosmaharani (2015) menunjukkan bahwa intervensi psikoedukasi keluarga dapat menurunkan kecemasan dalam merawat anak dengan retardasi mental.

Hasil penelitian pada kelompok kontrol menunjukkan bahwa rata-rata kecemasan sebelum perlakuan sebesar 58,85 (cemas ringan) dan sesudah perlakuan sebesar 52,90 (cemas ringan), terdapat penurunan kecemasan sebesar 5,95. Hasil analisis pada kelompok kontrol menunjukkan bahwa ada penurunan secara statistik dengan nilai $\mathrm{p}$ value $=0.00$ ( $\mathrm{p}$ value $<0.05)$. Hal ini menunjukkan bahwa terdapat perbedaan yang signifikan rata-rata kecemasan pada kelompok kontrol sebelum dan sesudah diberikan pendidikan kesehatan. Hasil penelitian Kurniawan, Armiyati \& Astuti (2013) menunjukkan bahwa ada pengaruh yang signifikan antara tingkat kecemasan sebelum dan sesudah diberikan pendidikan kesehatan pada pasien pre operasi hernia skrotalis yaitu dengan $\mathrm{p}$ value $=0,000<\alpha(0,05)$. Hal ini didukung pendapat Notoatmodjo (2010) bahwa pendidikan kesehatan mampu merubah pola pikir seseorang menjadi lebih positif.

Berdasarkan uraian diatas, terdapat selisih rata-rata skor kecemasan masingmasing kelompok yaitu didapatkan penurunan skor kecemasan sebesar 8,26 pada kelompok eksperimen dan penurunan skor kecemasan sebesar 5,95 pada kelompok kontrol. Dapat disimpulkan terdapat penurunan yang lebih tinggi pada kelompok eksperimen.

Thalassemia merupakan kelainan herediter atau bawaan sejak lahir yang terjadi dari kelahiran preterm ataupun prematur dan yang sampai dengan saat ini belum ada obat yang dapat menyembuhkannya (Padila, P., Amin, M., \& Rizki, R, 2018) sehingga keadaan ini memberikan dampak psikologis baik bagi penderita maupun orang tua dalam merawat anak dengan thalassemia. Dampak terhadap keluarga yang dijumpai antara lain yaitu: Permasalahan perawatan di rumah, permasalahan keuangan, dampak psikis keluarga dimana keluarga mengalami kecemasan (anxiety), tekanan emosional, ketakutan anaknya meninggal, perasaan bersalah, bersikap over protectif, gangguan tidur, merasa tidak berharga (Wong, 2009; Potts, Mandleco, 2007; Janerette, Valrie, 2010; Elsayed, 2015; Azizollah, tahmineh \& Abdulghaffar, 2014).

Setiap orang tua memiliki cara dan pengembangan tugas keluarga yang berbeda. hal ini tergantung terhadap budaya yang dikembangkan oleh suatu keluarga tersebut. Intervensi psychoeducational parentingdalam penelitian ini diberikan kepada responden melalui kegiatan pendidikan kesehatan tentang penyakit thalassemia dan manajemen cemas. Manajemen cemas yang diberikan kepada responden berupa pemberian latihan nafas dalam dalam mengatasi kecemasan yang dialami oleh responden sebagai dampak dalam merawat anak dengan thalassemia. Intervensi psychoeducational parenting dalam penelitian ini menggunakan metode ceramah, diskusi dan demonstrasi dalam kelompok kecil, juga memberikan leaflet tentang penyakit thalasemia kepada setiap responden.

Berdasarkan uraian diatas, peneliti berpendapat bahwa pendidikan kesehatan juga efektif dalam penatalaksaan terhadap psikososial seseorang terutama yang mengalami kecemasan. Sehingga terapi pendidikan kesehatan dapat menjadi alternatif penanganan kecemasan bila terapi psychoeducational parenting belum dapat dilakukan. Menurut peneliti terapi psychoeducational parentingmenjadi terapi lanjutan untuk menyelesaikan masalah psikososial termasuk kecemasan keluarga yang anggota keluarganya mengalami sakit fisik. 
Berdasarkan hasil penelitian, maka hasil pemodelan variabel yang menghasilkan nilai $\mathrm{p}<0,05$ yaitu variabel intervensi. Hasil ini menunjukkan bahwa variabel intervensi psychoeducational parenting merupakan faktor yang paling berhubungan dengan kecemasan orang tua yang mempunyai anak penyandang thalassemia mayor.

Psychoeducational yaitu terapi keperawatan kesehatan jiwa keluarga dengan cara pemberian informasi dan edukasi melalui komunikasi terapeutik, sehingga diharapkan tujuan dari terapi ini adalah meningkatkan pengetahuan dan menurunkan intensitas emosi seperti kecemasan melalui sumber kekuatan dalam keluarga itu sendiri (Stuart, 2013). Psikoedukasi tidak hanya bertujuan untuk membantu proses penyembuhan klien tetapi juga sebagai suatu bentuk pencegahan agar anggota keluarga klien dapat menghadapi kenyataan yang sedang dialaminya. Menurut Nelson-Jones (dalam Supratiknya, 2011) psikoedukasi mempunyai enam makna yaitu melatih orang mempelajari life skills, pendekatan akademik dalam mengajarkan psikologi, pendidikan humanistic, melatih tenaga professional di bidang keterampilan konseling, serangkaian kegiatan pelayanan kepada masyarakat dan memberikan pendidikan tentang psikologi kepada publik. Hal yang penting dari program psychoeducational parenting adalah bertemu dengan keluarga berdasarkan pada kebutuhan keluarga dan memberi kesempatan kepada keluarga untuk bertanya, bertukar pendapat dan bersosialisasi dengan anggota yang lain dan profesi kesehatan. Selain itu, disamping informasi dalam program psychoeducational parenting juga terdapat komponen latihan keterampilan yang terdiri dari komunikasi, latihan penyelesaian konflik, dan latihan mengatasi kecemasan. Lukens dan Mc Farlane (dalam Cartwright, 2007) mengutip beberapa hasil penelitian yang menunjukan bahwa intervensi psychoeducational dapat menurunkan gejala masalah kesehatan mental, khususnya dapat menurunkan kecemasan dan depresi. Pada akhirnya psychoeducational parenting diharapkan dapat mempengaruhi koping keluarga yang mempunyai anak penyandang thalassemia.

Hasil penelitian menunjukkan bahwa intervensi psychoeducational parenting ini merupakan faktor yang paling berhubungan dengan kecemasan orang tua yang mempunyai anak penyandang thalassemia mayor di RSUD Majalengka dibandingkan dengan faktor-faktor lain yang tidak diteliti. Berdasarkan pemodelan ringkas yang dapat menjelaskan hubungan variabel intervensi psychoeducational parenting dengan kecemasan dapat disimpulkan bahwa apabila tidak diberikan intervensi psychoeducational parenting akan meningkatkan skor kecemasan sebesar 2,318. Hasil analisis menunjukkan terdapat hubungan yang sangat lemah antara intervensi dan kecemasan. Beberapa faktor yang menyebabkan hal tersebut antara lain kompetensi pemberi psychoeducational parenting, motivasi dari responden untuk mengikuti psychoeducational parenting, pengalaman orang tua dalam merawat anak penyandang thalassemia serta faktor lain yang tidak diteliti. Seperti diungkapkan bahwa pendidikan kesehatan sangat dipengaruhi oleh motivasi individu untuk berubah. Kemampuan untuk mendapatkan pendidikan kesehatan tergantung pada faktor fisik dan kognitif, tingkat perkembangan, kesehatan fisik dan proses berfikir intelektual.

Perawat yang memiliki peran sebagai seorang edukator tentunya sangat diperlukan dalam hal ini. Perawat dapat menjalankan peran tersebut sebagai pemberi pelayanan untuk memberikan intervensi yang dapat menurunkan kecemasan dengan cara memberikan psychoeducational parenting. Psychoeducational parenting akan optimal jika dilakukan dengan strategi dan metode yang sesuai. Intervensi psychoeducational parenting dalam penelitian ini membantu menurunkan kecemasan pasien. 


\section{SIMPULAN}

Karakteristik untuk usia responden pada kelompok eksperimen rata-rata berusia 33,67 tahun dan pada kelompok kontrol rata-rata berusia 33,61 tahun. Lebih dari setengah responden pada kelompok eksperimen dan kontrol memiliki tingkat pendidikan rendah, lebih dari setengah responden pada kelompok eksperimen dan kontrol bekerja, memiliki pendapatan diatas UMR Kabupaten Majalengka dan sebagian besar responden mempunyai satu anak yang menyandang thalassemia dalam keluarga.

Rata-rata kecemasan responden pada kelompok eksperimen sebelum diberikan intervensi yaitu 59,5 dan kecemasan sesudah yaitu 50,28. Pada kelompok kontrol ratarata kecemasan sebelum yaitu 58,85 dan kecemasan sesudah yaitu 52,90.

Terdapat pengaruh psychoeducational parenting terhadap kecemasan orang tua yang mempunyai anak penyandang thalassemia mayor. Hasil penelitian ini membuktikan bahwa pemberian psychoeducational parenting sangat berpengaruh terhadap penurunan tingkat kecemasan orang tua yang mempunyai anak penyandang thalassemia mayor.

Tidak ada pengaruh faktor usia, pendidikan, pekerjaan, pendapatan keluarga dan keberadaan anak penyandang thalassemia dalam keluarga terhadap kecemasan orang tua yang mempunyai anak penyandang thalassemia mayor.

Hasil penelitian menunjukkan bahwa intervensi psychoeducational parentingpada kelompok eksperimen dan intervensi pendidikan kesehatan pada kelompok kontroldapat menurunkan kecemasan orang tua. Namun, penurunan kecemasan pada kelompok eksperimen lebih tinggi dibanding kelompok kontrol. Sehingga psychoeducational parenting lebih efektif menurunkan kecemasan orang tua yang mempunyai anak penyandang thalassemia mayor.

Pendidikan kesehatan dapat menjadi alternatif penanganan kecemasan bila terapi psychoeducational parenting belum dapat dilakukan. Menurut peneliti terapi psychoeducational parenting menjadi terapi lanjutan guna menyelesaikan masalah psikososial termasuk kecemasan yang dialami keluarga dengan anggota keluarga yang mengalami sakit fisik, terutama penyakit kronis.

\section{SARAN}

1. Hasil penelitian ini dapat dilanjutkan sebagai bentuk intervensi di rumah sakit yang dapat dijadikan sebagai pedoman dan program tetap dalam penatalaksanaan dampak psikososial bagi orang tua yang mempunyai anak penyandang thalassemia mayor.

2. Diperlukan peningkatan pengetahuan perawat melalui pendidikan formal misalnya spesialis perawat anak maupun non formal seperti pelatihan atau seminar, sehingga diharapkan akan mendapatkan peningkatan pengetahuan dan keterampilan perawat dalam memberikan pelayanan kepada pasien dan keluarganya, misalnya melalui pendidikan kesehatan dan konsultasi yang lebih mendalam sehingga keluarga mendapatkan gambaran yang jelas mengenai bagaimana proses penyakit dan penatalaksanaannya, serta dapat mengantisipasi hal-hal yang tidak diharapkan, sehingga dapat meningkatkan kesehatan dan kesejahteraan anak.

3. Perlunya dilakukan penelitian kualitatif untuk mengetahui lebih lanjut yang berkaitan dengan dampak psikososial yang dialami oleh orang tua maupun anak penyandang thalassemia.

4. Perlunya dilakukan penelitian mengenai intervensi psychoeducational parenting kepada orang tua yang mempunyai anak yang baru didiagnosa thalassemia. 


\section{DAFTAR PUSTAKA}

Astarani, K. (2016). Gambaran Kecemasan Orang Tua pada Anak dengan Thalasemia. Jurnal STIKES, 9(1), 20-25

Azizollah, Tahmineh \& Abdolghaffar. (2014). The Perception of Biological Experience in Patients with Major Thalassemia: A Qualitative Research. Global Journal of Health Science, 79-87

Cartwright, M.E. (2007). Psychoeducation among Caregivers of Children Receiving Mental Health Services. Disertation. Ohio; Graduate School of the Ohio State University

Cristensen. (2011). Effects of Group Psychoeducation for Parents of at-Risk Adolescents. UNF Theses and Dissertations. Paper 144

Donker, T. (2009). Psychoeducation for Depression, Anxiety and Psychological Distress: A Meta-Analysis. BMC Medicine, 7(1), p.79

Duran, S. (2016). Effectiveness of Psychoeducation Intervention on Subjective Well Being and Self Compassion of Individuals with Mental Disabilities. International Journal of Research in Medical Sciences, 4(1), 181-188

Elsayed.(2015). Nursing Guidelines for Children Suffering from Beta Thalassemia. International Journal of Nursing Science, 5(4), 131-135

Hockenberry, M.J., \& Wilson, D. (2015). Essentials of Paediatric Nursing. St. Louis : Elsevier-Mosby

Jenerette, C.M. \& Valrie, C.R. (2010).The Influence of Maternal Behaviors During Childhood on Self Efficacy in Individuals with Sickle Cell Disease. Journal of Family Nursing, 16, 422-434

Kemenkes RI. (2012). Thalasaemia Bukan Penyakit Menular. Jakarta: Pusat Komunikasi Publik Sekjen Kemenkes RI

Khairkar, A., Katyal, A., \& Marwaha, R. K. (2010). Psychosocial Burden in Thalasemia. Indian Journal of Pediatrics, 73(10), 877-880

Kurniawan A, Armiyati, \& Astuti R. (2013). Pengaruh Pendidikan Kesehatan Pre Operasi terhadap Tingkat Kecemasan pada Pasien Pre Operasi Hernia di RSUD Kudus. FIKkes jurnal Keperawatan, 6(2), 139 - 148

Lestari A. (2011). Pengaruh Terapi Psikoedukasi Keluarga terhadap Pengetahuan dan Tingkat Ansietas Keluarga dalam Merawat Anggota Keluarga yang Mengalami Tuberkulosis Paru di Bandar Lampung. Fakultas Ilmu Keperawatan UI. Jakarta

Mariana, D., Wulandari, D., \& Padila, P. (2018). Hubungan Pola Makan dengan Kejadian Anemia pada Ibu Hamil di Wilayah Kerja Puskesmas. Jurnal Keperawatan Silampari, $\quad 1(2), \quad 108-122$. https://doi.org/https://doi.org/10.31539/jks.v1i2.83

Notoatmodjo, S. (2010). Ilmu Perilaku Kesehatan. Jakarta: Rineka Cipta

Nurhidayah. (2010). Ilmu Perilaku dan Pendidikan kesehatan untuk Perawat. Medan: USU Press

Old, J. (2013). Prevention of Thalassaemias and Other Haemoglobin Disorders. Tif Publication, (18). Cyprus: Publishers Thalassaemia International Federation

Padila, P., Amin, M., \& Rizki, R. (2018). Pengalaman Ibu dalam Merawat Bayi Preterm yang Pernah dirawat di Ruang Neonatus Intensive Care Unit Kota Bengkulu. Jurnal Keperawatan Silampari, $\quad$ 1(2), 1-16. https://doi.org/https://doi.org/10.31539/jks.v1i2.82

Panja, A. (2012). Genetics of Thalassemia in Indian Population. Journal of Community Nutrition dan Health, 1(1), 39-46 
Pots, N.L., \& Mondleco, B.L. (2007). Pediatric Nursing; Caring for Children and Their Families (2nd ed). New York: Thomson Corporation

Riset Kesehatan Dasar (Riskesdas). (2013). Badan Penelitian dan Pengembangan Kesehatan Kementerian RI tahun 2013

Rosmaharani, S. (2016). Pengaruh Psikoedukasi Keluarga terhadap Perubahan Tingkat Kecemasan dan Persepsi Beban Keluarga dalam Merawat anak dengan Retardasi Mental di SLB Negeri Kabupaten Jombang

RSUD Majalengka. (2016). Rekam medik RSUD Majalengka Tahun 2016. Majalengka

Sastroasmoro, S. dan Ismael, S. (2011). Dasar-Dasar Metodologi Penelitian Klinis. Edisi keempat. Jakarta: CV. Sagung Seto

Stuart, G. W. (2009). Buku Saku Keperawatan Jiwa. Jakarta: Penerbit Buku Kedokteran EGC

(2013). Principles and practice of Psychiatric Nursing, $10^{\text {th }}$ edition. Mosby

Supratiknya, A. (2011). Merancang Program dan Modul Psikoedukasi. Edisi Revisi. Yogyakarta: Universitas Sanata Dharma

Taher, A. (2013). Guidelines for the Management of Non Ransfusion Dependent Thalassaemia (Ntdt), Tif Publication, (19). Cyprus: Publishers Thalassaemia International Federation

Tamam, M. (2009). Pekan Cegah Thalasemia. Thalassemia. Indonesia Rotari Internasional

Thallassemias International Federation (TIF). (2011). Guidelines for the Clinical Management of Thalassaemia. Tersedia online: [http://www.thalassaemia.org.cy]

Wahyu, H., Betrianita, B., Pramesti, M., \& Padila, P. (2018). Pengaruh Metode Glenn Doman (Tahap 1 Dan 2) terhadap Perkembangan Komunikasi Anak Autisme di Autis Center Bengkulu. Jurnal Keperawatan Silampari, 2(1), 169-183. https://doi.org/https://doi.org/10.31539/jks.v2i1.306

Wahyudi. (2011). Jawa Barat Ranking 1 Penderita Thalassemia, http://web.rshs.or.id, diperoleh tanggal 10 Maret 2017

Walsh J. (2010). Psychoeducation in MentalHealth. Lyceun Books Inc: Chicago

Widyaningrum. (2015). Pengaruh Family Psychoeducation terhadap Peningkatan Pengetahuan dan Penurunan Kecemasan Keluarga dalam Merawat Penderita Kanker Serviks di Rsud Dr. Moewardi Surakarta. The Indonesian Journal of Health Science, 5(2), 165-175

Wong, D. L. (2009). Buku Ajar Keperawatan Pediatrik Edisi 6 Volume 1 (Andry Hartono, Sari Kurnianingsih, dan Setiawan, penerjemah). Jakarta: EGC

Zikrillah. (2016). Pengaruh Psikoedukasi terhadap Masalah Psikososial Keluarga yang Memiliki Anggota Keluarga dengan Masalah Kesehatan Kronis: Sebuah Literature Review. Jurnal Ilmiah Ilmu-Ilmu Kesehatan, 14(2)

Zulfan, S. (2012). Psikologi Keperawatan. Jakarta: PT. Raja Grafindo persada 